\title{
The Legal Strength of Physical (Sporadic) Ownership Letters as the Basis for Land Rights (Analysis of the Jantho District Court Decision No.12/Pdt.G/2020/PN- $\mathrm{JTH})$
}

\author{
Suhaimi, Roslaini Ramli, EnzusTinianus, Indra Kesuma Hadi, Chadijah Rizki Lestari \\ Lecturer, Faculty of Law, Syiah Kuala University, Banda Aceh, Indonesia
}

\begin{abstract}
This study analyzes how the legal force of a physical (sporadic) letter of control over a plot of land. In practice, many owners of a plot of land do not have evidence to prove their property. Control over a plot of land without the support of written evidence will affect its ownership and transfer of land rights to other parties, and can even lead to disputes in court. This research only focuses on normative legal research (normative juridical), namely research that focuses on studies of documents from various primary data such as judges' decisions, laws and regulations, expert opinions and others. Meanwhile, the data collection technique was carried out by collecting primary legal materials, secondary legal materials, and tertiary legal materials. According to the results of the study, it is known that the Statement of Physical Control of Land (Sporadic) has perfect legal force such as an authentic deed, if the sporadic has been tested for truth and has been proven in front of the court, even sporadic is in accordance with the facts revealed in court. The parties who signed in the Sporadik confirmed their signatures and were confirmed by the signatures of the Village Head (KeuchikGampong) and the Camat as the local District Head.
\end{abstract}

\section{INTRODUCTION}

The existence of Law Number 5 of 1960 concerning Basic Regulations on Agrarian Principles (UUPA), one of which aims to provide the basics in order to guarantee legal certainty regarding land rights for all Indonesian people. The UUPA basically gives responsibility to the government to carry out land registration in accordance with Article 19 of the UUPA which aims to:

1. "Providing certainty regarding the person or legal entity who is the holder of land rights, which is called the certainty of the subject of land rights;

2. Provide certainty of the location, length and width of the land or the total area, boundaries of the land parcel, called with certainty about the object on the land".

The implementation of land registration as referred to in Article 19 of the UUPA aims to "provide legal certainty and legal protection for registered lands. The implementation of land registration is the obligation of the government and the holder of land rights, in accordance with Article 19 paragraph

${ }^{1}$ IrwanSoerodjo, KepastianHukum Hak Atas Tanah Di Indonesia, Arkota, 2003, Surabaya, p. 78.
(1) of the UUPA which states that the Government carries out land registration throughout Indonesia, namely to ensure legal certainty. This is regulated by Government Regulation".2As a realization of these provisions, Government Regulation (PP) Number 10 of 1961 concerning Land Registration, which then because it was deemed that the PP could no longer accommodate the development of the times, PP Number 24 of 1997 concerning Land Registration.As a follow-up to the implementation of land registration, "a letter of proof of ownership of land rights is given by the government called a certificate. This certificate is a strong evidence in which it contains physical data and juridical data on a plot of land, as long as the juridical data and physical data are in accordance with the data contained in the letter of measurement and the book of land rights concerned. Certificates are also strong evidence as long as there are no claims from other parties who feel they have rights to the land within a period of 5 (five) years from the issuance of the certificate. This is as explained in Article 32 paragraph (2) of PP Number 24 of 1997".

The possession of a plot of land that has not been certified does not mean that the parcel of land does not receive legal protection at all. Especially for lands controlled by customary law or controlled for generations and do not have any evidence to prove that the land is his property. Control over a plot of land without the support of written evidence will affect its ownership and transfer of land rights to other parties, and can even lead to disputes in court.

In the sale and purchase of rights to customary land or land controlled according to customary law that does not yet have a certificate or other evidence, usually the sale and purchase is carried out on the basis that the rights are physical (sporadic) letters of control. So that in the sale and purchase of the land, the Land Deed Making Official (PPAT) in making the Sale and Purchase Deed (AJB) is only based on a physical (sporadic) letter of control made by the land owner in question and strengthened by witnesses (2 witnesses) with the knowledge of the local Village Head (KeuchikGampong).

\footnotetext{
${ }^{2}$ Della RafiqaUtari, Suhaimi, Pendaftaran Tanah Yang DikuasaiOlehTempattempatIbadahUmat Islam Di KecamatanKutaAlam Banda Aceh, Syiah Kuala Law Journal (SKLJ), Vol.4(3), 2020, p. 311.
} 
Furthermore, for legal certainty and legal protection, the buyer registers the land rights obtained through the sale and purchase to the Land Office to obtain a certificate.

Sometimes the making of AJB by PPAT which is based on a physical letter of control (sporadic) creates legal problems or disputes in the community. For example, the case that occurred within the jurisdiction of the Jantho District Court of Aceh Besar District, namely the case with Case Register Number 12/Pdt.G/2020/PN-JTH. In this case the land was controlled by the Defendant more than 40 years ago and the control over the land was only based on a Statement of Physical Control of the Land Sector (Sporadic), which then the Defendant sold the land to a person named Sri Mulyani. The sale and purchase was carried out with AJB made by PPAT Mukhsin, S.H. who is also a Notary in Aceh Besar District.

In the above case, the Plaintiff stated that the land was his and the physical (sporadic) control letter made by the Defendant and witnessed by 2 (two) witnesses and confirmed by the Village Head (KeuchikGampong) was invalid and had no legal force. Therefore, it is necessary to conduct a study on how the legal force of a physical (sporadic) letter of control over a plot of land in the process of buying and selling land rights is carried out, even though this study only analyzes the Jantho District Court Decision Number of Case Register 12/Pdt.G/ 2020/PN-JTH. So that later such cases will not be repeated in the community, and the PPAT can be more careful in making $\mathrm{AJB}$ in the process of buying and selling land which is only based on physical (sporadic) control letters.

This research only focuses on normative legal research (normative juridical), namely "research that focuses on studying documents from various primary data such as judges' decisions, laws and regulations, opinions of experts or legal experts and others. The approach in this study uses a statutory approach and a case approach as the focus of research. Meanwhile, the data collection technique was carried out by collecting primary legal materials, secondary legal materials, and tertiary legal materials. The data obtained were then analyzed qualitatively", 3

\section{THE IMPORTANCE OF THE PEDESTRIAN OF LAND RIGHTS AND LAND REGISTRATION}

The Basic Agrarian Law (UUPA) as regulated in Law Number 5 of 1960 has "laid the foundation for the preparation of national agrarian law and laid the foundation for legal certainty over land rights for the Indonesian people". Therefore, the government has the obligation to carry out the registration of land rights throughout Indonesia. However, it cannot be denied that in practice there are still many lands that are controlled by the community that have not been registered with the Land Office, and there are even lands that do not

\footnotetext{
${ }^{3}$ Muyassar, Dahlan Ali, $\quad$ Suhaimi, "PertanggungjawabanHukumNotarisTerhadapPengingkatanAktaJualBeli Tanah BersertifikatOlehPihak Yang Dirugikan", Syiah Kuala Law Journal (SKLJ), Vol. 3(1), April 2019, p. 153.
}

have any evidence in their control, so that it has resulted in disputes in the community. In this case, it is like the case that happened to a plot of land located in the district of Aceh Besar which covers an area of about $806 \mathrm{M} 2$, where the land was controlled by the Defendant more than 40 years ago. The control of the land rights is not based on any rights and its control is only based on the Statement of Physical Control of the Land Sector (Sporadic) made by the person concerned and known and confirmed by 2 (two) witnesses and the Village Head (KeuchikGampong), who then The defendant sold the land to Sri Mulyani with AJB made by PPAT Mukhsin,SH.

The case referred to above was submitted to the Jantho District Court with Case Register Number 12/Pdt.G/2020/PNJTH, and sued to cancel AJB made by PPAT Muchsin,SH, because according to the Plaintiff the AJB had no power whatsoever. because the making of AJB is only based on Sporadic Letters and is not supported by other rights. In fact, this case will not occur if the land owner has previously taken care of and has proof of ownership of the land as the basis for the rights to the land he controls. For example:

- If the land is obtained from the inheritance of his parents, there must be a letter or deed regarding the distribution of the inheritance and the respective shares obtained by the heirs.

- If the land was obtained from the gift of his parents (Grant), there is a letter or deed proving that the land has been granted to him.

- If the land is obtained due to the exchange of land rights, there must be a letter (deed) of exchange for the land in question.

- If the land is acquired due to the sale and purchase of land rights, there must be a letter (deed) namely AJB for the land in question.

The documents of evidence are very important to prove the ownership of a plot of land, even "if the land is to be registered with the Land Office, then according to Article 24 paragraph (1) PP Number 24 of 1997 the land can be proven by means of evidence. other written evidence that can prove the existence of such rights, in addition to witness statements and/or statements in question which are deemed sufficient for the purpose of registering their rights at the Land Office". 4

Legal certainty means that it can be known with certainty and clearly who is the holder of the land rights and what the object of the land rights is. Guarantees of legal protection are given to holders of land rights that have been certified when there are other parties who file a lawsuit or claim from other parties for the ownership of someone's land rights. legal land rights". 5 In addition, Article 32 paragraph (1) of Government Regulation Number 24 of 1997 states that "Certificates are evidence of rights that apply as a strong evidence tool

\footnotetext{
${ }^{4}$ Ilyas Ismail, SertifikatSebagaiAlatBuktiHakAtas Tanah Dalam Proses Peradilan, KanunJurnalImuHukum, Vol. 13(1), 2011, p. 28.

${ }^{5}$ FandriEntimanNae, KepastianHukumTerhadapHakMilikAtas Tanah Yang SudahBersertifikat, JurnalLexPrivatum, Vol.1 No.5 November 2013, p.55-56.
} 
regarding physical data and juridical data contained therein, as long as the physical data and juridical data are in accordance with contained in the letter of measurement and the land book concerned". This provision implies that as long as the contrary has not been proven, physical data and juridical data included in the certificate must be accepted as correct data, both in daily legal actions and in disputes in court, as long as the data is in accordance with what is stated in the letter measuring and the relevant land book.

\section{LEGAL STRENGTH OF PHYSICAL LETTER OF CONTROL (SPORADIC)}

In analyzing the legal force of physical possession (Sporadic), the following will present the essence of the case submitted to the Jantho District Court with Case Register Number. 12/Pdt.G/2020/PN-JTH. In this case the Plaintiff stated that the land sold by Defendant I to Defendant II was his land. The sale and purchase process was carried out in front of Defendant III as the Land Deed Making Officer (PPAT) with the Sale and Purchase Deed (AJB) Number 659/2019 dated September 24, 2019. The AJB was also witnessed and signed by the Witness as the Village Head (KeuchikGampong) where the land is located. Defendant I controlled the land as an inheritance from his dead parents, but the land did not have any certificates, either private deed or authentic deed. Then on September 24, 2019 Defendant I sold the land to Defendant II in accordance with AJB Number 659/2019 dated September 24, 2019.

Since the land does not have documents that can prove that the land belongs to Defendant I, before the AJB was made, Defendant I made a Statement of Physical Control of the Land Sector (Sporadic) which was known and signed by 2 (two) witnesses and the Village Head ( KeuchikGampong) and the sub-district head as the local sub-district head. After Defendant I sold his land rights to Defendant II, suddenly the Plaintiff appeared saying that the land that had been sold under AJB Number 659/2019 on September 24, 2019 was his land. However, the Defendant denied the Plaintiff's statement, so that in the end the Plaintiff filed a lawsuit against Defendant I, Defendant II and Defendant III. In the lawsuit, the Plaintiff proved his statement by presenting a number of witnesses, including the witness who challenged the Sporadic Letter and also KeuchikGampong", ${ }^{6}$

The Plaintiff's obligation to prove his statement is in accordance with "one of the most important principles in proving civil cases, namely the principle of actori in cambitprobatio contained in Article 1865 of the Civil Code (KUH-Perdata) which states that: that he has a right, or, in order to confirm his own right or to refute a right of another person, refers to an event, he is required to prove the existence of that right or event.In proving the rights as referred to in Article 1865 of the Civil Code, then according to Article 1866

6

https://www.hukumonline.com/klinik/detail/ulasan/lt58ddaa2675aa7/dampakhukum-putusan-hakim-yang-berdasarkan-pada-bukti-palsu/ of the Civil Code "the deed has a very important position in proving a case in court. The deed itself is divided into 2 (two) types, namely authentic deed and private deed. According to Article 1870 of the Civil Code, it has absolute and binding evidentiary power, in the sense that what is stated in the authentic deed is perfect evidence, therefore it does not need to be proven by another deed or other evidence, as long as the untruth contained in the authentic deed it cannot be proven". ${ }^{7}$

A deed is said to be authentic because "the deed was made by an authorized official such as a notary. A notary is a public official who is given the authority based on laws and regulations to make an authentic deed of all actions, agreements and stipulations, either because it is desired by the laws and regulations or the will or desired by the parties".

Meanwhile, an underhand deed is "a deed or letter that is not made before a public official, but is made by interested parties which is intended to be used as evidence. Furthermore, the letter or deed under the hand made by the parties is affixed with a signature.

Based on the description above, in the case handled by the Jantho District Court, the Plaintiff could not prove the existence of a deed regarding the ownership of his land rights, both an authentic deed and a private deed, even if there were witnesses who stated his ownership. However, the witness testimony is not supported by other evidence. So what is required in Article 1865 of the Civil Code that "Everyone who states or argues that he has a right, or, in order to confirm his own right or refute a right of another, refers to an event, is required to prove the existence of a right or event. said, the Plaintiff cannot argue it. Thus, what was requested by the Plaintiff in his lawsuit to the Jantho District Court Judges to "cancel and declare the Declaration of Physical Control of Land (Sporadic) which was also signed by Defendant II as the Village Head (KeuchikGampong) must be declared invalid and legally invalid.", is unwarranted and there is not enough evidence to support it. Likewise, the Plaintiff's request to the Panel of Judges to "Cancel and declare the Sale and Purchase Deed (AJB) made by Defendant III must be declared invalid and has no legal force", also without reason and insufficient evidence for that.

Meanwhile, Defendant I who controls or has land rights as evidenced by a deed or private letter, namely a Statement of Physical Control of Land (Sporadic) which is made to prove that it is his land, according to the consideration of the Panel of Judges the sporadic letter is sufficient to prove that the land belongs to Defendant I. This is in accordance with Article 1865 of the Civil Code which states that anyone who argues against another person's right must be able to prove that another person does not have the right to something and he is

\footnotetext{
${ }^{7}$ Malahayati, Syahrizal Abbas, Dahlan, KekuatanHukumAktaHibahUntukAnakAngkat, KanunJurnalIlmuHukum, Vol. 21(2), Agustus 2019, p. 195-196.

${ }^{8}$ Ibid.,p. 497.
} 
the one who has the right with the support of evidence adequate.

Based on the description above, the Panel of Judges of the Jantho District Court in their consideration stated that:

1. In the buying and selling process, Defendant II has gone through the procedures or mechanisms regulated in the laws and regulations, and the documents shown by the parties are legal documents and the sale and purchase is carried out before the Land Deed Making Official (PPAT) in accordance with the provisions Government Regulation Number 27 of 1997. This can be seen with the existence of AJB Number 659/2019 on September 24, 2019.

2. Defendant I as the legal owner of the land and sells it to Defendant II as evidenced by the existence of a statement of ownership from Defendant I (the seller) in the form of a Statement of Physical Control of Land Sector (Sporadic) which is known and signed by the Village Head (KeuchikGampong) and the Camat local district.

3. To declare that the disputed land which has been purchased by Defendant II from Defendant I is the legal property of Defendant II.

In particular regarding the Statement of Physical Control of the Land Sector (Sporadic), the Panel of Judges provides legal considerations as follows:

1. That the Letter of Physical Control of Land (Sporadic) which was made on July 23, 2019 proves that Defendant I has physically controlled the land (now as the object of dispute) for a long time and the evidence is known and signed by 2 (two) witnesses (HasballahDaud and Tgk. RashidinDaud). Then the Declaration of Physical Control of the Land Sector (Sporadic) was signed by the Village Head (KeuchikGampong) and also signed by the Camat as the local District Head.

2. Physical Control of Land (Sporadic) has been confirmed by 2 (two) witnesses, namely Tgk. RasyidinDaud and HasballahDaud in front of the court, where basically the witnesses had signed the Sporadic Letters made for Defendant I. That the signatures on the Sporadic Letters were indeed the signatures of the witnesses. That the witnesses had signed the Sale and Purchase Deed (AJB) Number 659/2019, which was made by PPAT Muchsin, SH. based on the Sporadic Letter. That the deed that the witnesses signed was the Sale and Purchase Deed (AJB) Number 659/2019 and when the witnesses signed the AJB there was no coercion and pressure from other parties.

3. Declaration of Physical Control of Land (Sporadic) although the form is a private deed and not made by an authorized official, but the letter has perfect legal force (such as an authentic deed), because the person signing the letter has confirmed that the challenge is his signature. Thus, if there are other parties who deny it, the strength of the proof is still perfect if the other party cannot prove the denial.

4. Based on the evidence presented by the Plaintiff as described above in relation to one another, the Panel of Judges is of the opinion that the main argument of the Plaintiff's claim, which states that the land object of dispute belongs to the Plaintiff, cannot be proven by the Plaintiff. On the other hand, Defendant I, Defendant II and Defendant I can prove their denial argument.

5. Since the Plaintiff was unable to prove the main arguments of his lawsuit and thus the main petition in this case was rejected, the other petitions must be declared rejected, so that the Plaintiff's claim was rejected in its entirety according to law.

Thus it can be understood that based on the consideration of the Jantho District Court Judges in the Case Register Number 12/Pdt.G/2020/PN-JTH which already has permanent legal force, it can be explained that the land rights controlled by Defendant I are based on the Physical Control Statement. Land Sector (Sporadic), is land belonging to Defendant I. Then, the Statement of Physical Control of the Land Sector (Sporadic) has perfect legal force because it has been tested for truth and has been proven before a court hearing, and the contents of the letter are in accordance with the existing facts. In this case, the parties who put their signatures in the Declaration Letter of Physical Control of the Land (Sporadic) confirmed their signatures and were confirmed by the signatures of the Village Head (KeuchikGampong) and the Camat as the local District Head. Thus, 2 (two) witnesses and the GampongKeuchik and the Camat are parties who know the truth of the contents of the Statement of Physical Control of Land (Sporadic). So that the Statement of Physical Control of the Land (Sporadic), even though it is a private deed, has perfect evidence strength as well as an authentic deed.

\section{CONCLUSION}

Letters of proof of rights to a plot of land as the basis for land rights are very important things to prove ownership of a plot of land, even if the land is to be registered with the Land Office, then according to Article 24 paragraph (1) PP No. 24 of 1997 the land can be proven by other written evidence that can prove the existence of such rights. In addition, witness statements and/or statements in question are deemed sufficient for the purpose of registering their rights at the Land Office, including the basis or basis of rights to prove ownership of a land right.

According to the consideration of the Jantho District Court Judges in the Case Register Number 12/Pdt.G/2020/PN-JTH, the Declaration of Physical Control of the Land Sector (Sporadic) has perfect legal force such as an authentic deed. This is because the sporadic has been tested for truth and has been proven in front of the court, even the contents of the sporadic letter are in accordance with the facts that were revealed in court. The parties who put their signatures in the 
Sporadic Letter, such as 2 (two) witnesses confirmed their signatures and were confirmed by the signatures of the Village Head (KeuchikGampong) and the Camat as the local District Head. Thus, 2 (two) witnesses and the GampongKeuchik and the Camat are parties who know the truth of the contents of the Statement of Physical Control of Land (Sporadic). So that the Statement of Physical Control of the Land (Sporadic), even though it is a private deed, has perfect evidence strength as well as an authentic deed.

\section{BIBLIOGRAPHY}

Books, Journal, Website

[1] Dahlan, KesaksianNotarisTerkaitPemalsuanSurat Di BawahTangan, KanunJurnalllmu Hukum, Vol. 16(3), Desember, 2014.

[2] Della RafiqaUtari, Suhaimi, Pendaftaran Tanah Yang DikuasaiOlehTempat-tempatIbadahUmat Islam Di KecamatanKutaAlam Banda Aceh, Syiah Kuala Law Journal (SKLJ), Vol.4(3), 2020.

[3] FandriEntimanNae,KepastianHukumTerhadapHakMilikAtas Tanah Yang SudahBersertifikat, JurnalLexPrivatum, Vol.1 No.5 November 2013.
[4] https://www.hukumonline.com/klinik/detail/ulasan/lt58ddaa2675a a7/dampak-hukum-putusan-hakim-yang-berdasarkan-pada-buktipalsu/.

[5] Ilyas Ismail, SertifikatSebagaiAlatBuktiHakAtas Tanah Dalam Proses Peradilan, KanunJurnalllmuHukum, Vol. 13(1), 2011.

[6] IrwanSoerodjo, KepastianHukum Hak Atas Tanah Di Indonesia, Arkota, 2003, Surabaya.

[7] Malahayati, Syahrizal Abbas, Dahlan, KekuatanHukumAktaHibahUntukAnakAngkat,KanunJurnalIlmu Hukum, Vol. 21(2), Agustus 2019.

[8] Muyassar, Dahlan Ali, Suhaimi, "PertanggungjawabanHukumNotarisTerhadapPengingkatanAktaJu alBeli Tanah BersertifikatOlehPihak Yang Dirugikan", Syiah Kuala Law Journal (SKLJ), Vol. 3(1), April 2019.

Law and Regulations

[1] Constitution of the Republic of Indonesia.

[2] Law Number 5 of 1960 concerning Basic Regulations on Agrarian Principles.

[3] Civil Code (Burgerlijk Wet Boek).

[4] Government Regulation of the Republic of Indonesia Number 24 of 1997 concerning Land Registration.

[5] Regulation of the Minister of State for Agrarian Affairs/Head of the National Land Agency Number 3 of 1997 concerning Provisions for the Implementation of Government Regulation Number 24 of 1997 concerning Land Registration.

[6] Jantho Register District Court Decision Number 12/Pdt.G/2020/PNJTH. 